Institute of Internet and Intelligent Technologies

Vilnius Gediminas Technical University

Saulètekio al. 11, 10223 Vilnius, Lithuania

http://www.isarc2008.vgtu.lt/
The $25^{\text {th }}$ International Symposium on Automation and Robotics in Construction

June 26-29, 2008

ISARC-2008

\title{
ASSESSMENT OF LITHUANIAN ENERGY GENERATION COMPANIES' INFRASTRUCTURE COMBINED WITH SUSTAINABLE ENVIRONMENT PRINCIPLES
}

\author{
Jūratė Šliogerienè \\ Vilnius Gediminas Technical University \\ Civil engineering faculty \\ Saulètekio al. 11, LT-10223 Vilnius, Lithuania \\ Jurate.Sliogeriene@st.vgtu.lt
}

\author{
Mindaugas Krutinis \\ Vilnius Gediminas Technical University \\ Civil engineering faculty \\ Sauletekio al. 11, LT-10223 Vilnius, Lithuania \\ Mindaugas.Krutinis@st.vgtu.lt
}

\begin{abstract}
The main task of the energy sector of today is reliable generation of safe, ecologically clean, effective and economically perspective energy. This objective may be implemented by forming the energy sector management policy, by changing and defining management and operational costs, and by assessing the impact of energy infrastructure on ecology. Therefore, the need emerges to estimate various aspects of electricity production, transmission and distribution activity by more exhaustive methods, applying environmental assessment, developing and establishing ways that may become helpful in the decision making process.

At the moment the nuclear power plant still operating in Lithuania generates about $80 \%$ of the needed power output. After this power plant is closed down in 2009 , the situation of energy generation will change markedly in Lithuania.

The reliability of energy supply and environmental assessment serve as the ground while preparing to accept strategic decisions, which would reconcile the growing demand for energy, technological complexity and environmental problems. An extremely important factor that shows the ecological compatibility of the system is the establishment of the role of environmental protection and the consolidation of its priority role in the energy system.

Therefore, ecological integration and technological innovation is presented as the main features that need assessment in order to assure fully environmentally safe energy production and transmission structure. Searching for methods of solving these issues, it is necessary to apply management and analysis methods that would combine ecological, social, technological aspects of the energy system with the sustainable environmental analysis.
\end{abstract}

\section{KEYWORDS}

Energy Generation Companies, Sustainable Environment, Multiple Criteria Decision Support 


\section{GENERAL INSTRUCTIONS ENERGY INFRASTRUCTURE DEVELOPMENT TASKS}

The economy of any country may be evaluated according to the development level of its energy infrastructure. Economic development is directly related with infrastructure adapted to industrial development possibilities and supply of energy resources. Therefore, the growing price of energy resources and expensive infrastructure is becoming the key issue while solving questions of economic development and integration; and this factor may turn into the one that influences the speed of economic growth of the country the most. Attention of the society to energy sector development is related to the need of welfare growth as well as the aspiration to have safe and ecologically harmonised environment.

The activity of electricity production, transmission and distribution assures the supply of energy resources and thus creates the ground for welfare of the society. However, the side effect of this activity is the rapid use of non-renewable resources and negative impact on the surrounding environment. Operating power plants that use organic fuel emit $\mathrm{SO} 2, \mathrm{NOx}, \mathrm{NH} 3$ as side combustion products and other hazardous particles to the environment, hightension transmission networks cause an increased electromagnetic radiation. These factors harm the biological variety of environment, human health and activity products of people, i.e., the quality of agriculture products, buildings, construction materials, etc.

While performing its activity and estimating energy production or transmission costs, an electricity producer estimates costs related to environment protection. Environment protection costs encompass all ecology measures applied by the company: from expenses to the evaluation of particular work places from the health protection point of view, equipment and devices that reduce harmful effect, purchase of more ecological fuel and more effective technologies, property operation and amortisation deductions that enable to accumulate funds for the upgrade of technologies to taxes for the use of natural resources and pollution permits. However, such applied measures are not sufficient to fully regard the effect made on the environmental system. There exist environmental protection costs that are not related to direct production costs incurred by the company, such costs are "external", even though due to this specific activity the society also incurs expenses, which are "relegated" to the health care system or groups of inhabitants that experience losses due to low-quality agricultural products and additional property operational costs. Thermal power stations that use organic fuel - coal, fuel oil, gas - make the greatest impact on the environment in the electricity sector.

It is stated in the report on energy resources announced by the World Energy Council in 2001 that "there are sufficient resources in every region of the world that would satisfy the growing energy demand even in the 21 st century; however, there are no new special technologies that would markedly reduce the part of organic fuel in the general energy balance in the nearest future". This is why sustainable development of the energy system and efforts to combine rational production limiting down the use of resources, maximal efficiency and reduction of negative impact on the environment are becoming significant tasks. It is known that fuel costs form slightly more than one third of costs in the structure of energy production costs at thermal power stations. The remaining part of costs is capital and management costs. In wind and hydro power plants, the capital and management costs form up to 95 percent of all costs. Therefore, it is important to apply effective property management methods of energy infrastructure including property accounting.

According to the 2001/77/EC Directive of the European Union Parliament and Council as of July 27, 2001, member states should endeavour that the part of renewable energy would make more than $12 \%$ in the general energy balance and $22.1 \%$ in the electricity balance of the country including hydro power plants in year 2010. In the National Energy Strategy, Lithuania confirms its obligations to the European Union regarding the implementation of greater use of renewable energy resources for electricity generation. After constructing wind power plants and thermal power stations using biomass fuel, the part of renewable resources in the 
general electricity production balance will make about $7 \%$ by year 2010 . At the moment energy production from renewable resources, including hydro energy, amounts to $4 \%$. As the economy of Lithuania is growing and the demand for electricity is increasing, the planned decommissioning of Ignalina Nuclear Power Plant in 2009 will have an essential impact on the supply of reliable electric power (Figure 1).

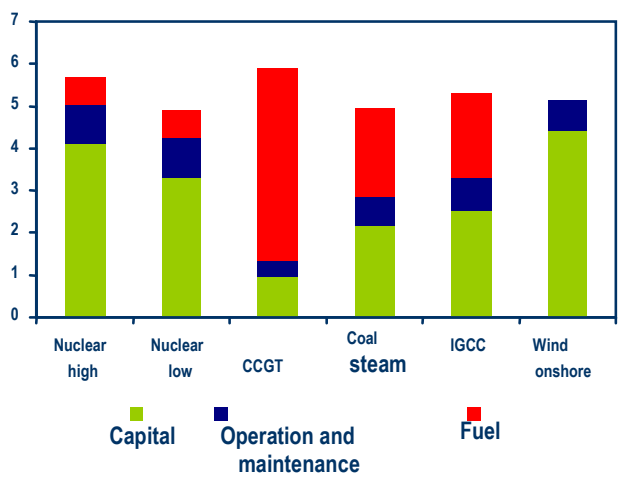

Figure 1. Comparative generation costs (US cent $/ \mathrm{kWh}$ )based on low discount rate (according to IEA: Nuclear Power Generation Costs)

Presently up to $80 \%$ of electricity necessary for the needs of Lithuania is generated at Ignalina NPP. Nuclear power uses relatively small amounts of nuclear fuel in the generation process, its transportation is not complicated, its impact on the environment is not big, very small amounts of hazardous substances and substances causing "heat effect" are emitted to the environment. The use possibilities of the majority of renewable energy resources potential are limited; therefore, the use of renewable energy resources will form an essential technological part in the world energy balance only after 30-40 years [8]. Thus, it would not be possible to secure satisfaction of the society needs without the created, operating and regularly upgraded and modernised production, transmission and distribution infrastructure. The surging price of energy resources and its generation will encourage to consider all possibilities of reducing production costs by implementing technologies saving resources, by assessing the necessity of ecological measures and by applying rational management methods. As new requirements for infrastructure management are set and attempts are made to control and reduce its impact on the environment, it is necessary to search for new methods of infrastructure property management, assessment and analysis [5].

\section{FEATURES OF ENERGY INFRASTRUCTURE}

Solving issues of balanced development and operation, accepting management solutions, it is important to assess the production, transmission and distribution costs that would cover both - direct internal costs and external environmental impact assessment costs.

The level of internal production, transmission and distribution costs directly depends on the value of property used for activity, incurred operational costs, amortisation deductions. Therefore, the accounting of assessed correct property value in companies' accounting documents is one of the more important indexes while calculating the production, transmission and distribution costs. This is also required by International Accounting Standards regulating companies' property accounting.

The infrastructure of energy sector - property for energy production, transmission and distribution forms a very significant part in the economy of every country. The biggest part of property of energy infrastructure companies is special-purpose property: technological lines, devices, equipment, pipelines, cable and overhead power transmission and distribution lines, transformer substations and switchyards, hydro-technical constructions and installations, wind power plant equipment, etc. Property of the energy sector, constructions and equipment, serve for a long period of time - from several to several dozens of years; technological changes are slow, renewal requires extremely large investments and the payback time is long. Therefore, combining operational measures, new technologies function in the common system along with effectively serving property and conservative technologies, which do not save resources and which are often electrotechnical property items created in a non-rational way. 
Infrastructure is a limiting element in the energy sector, and it influences the operation of the entire energy system the most. Gradual modernisation of the system, replacement of technologies by more reliable, rational and environmentally-friendly ones, rational property management decisions and suitable accounting of property are the features of a contemporary company of energy infrastructure. Implementing these purposes, it is also equally important to establish suitable depreciation norms that would enable to accumulate funds for property renewal. The property of energy infrastructure wears technologically the most rapidly, while the period of physical operation of a property item may be much longer. Amortisation deductions of a property item are accounted as internal costs of a company; still, they create positive cash flows. It is also important that the property depreciation would be calculated from the correctly established value of a property item. Depreciation deductions from property that has not been assessed suitably will not result in sufficient funds necessary for the property renewal. Meanwhile, overvalued property will increase the level of company costs, will have negative impact on profitability and other activity indexes. This is why the correct establishment of value of infrastructure property is significant in the property accounting and management processes.

\section{WEB-BASED MULTIPLE CRITERIA DECISION SUPPORT SYSTEM FOR POWER-STATION SUSTAINABLE DEVELOPMENT ANALYSIS}

Based on an analysis of the existing information systems, neural networks, genetic algorithms, fuzzy, knowledge-based and decision support systems and in order to determine the most efficient versions of power-station, a Web-Based Multiple Criteria Decision Support System for Power-Station Sustainable Development Analysis was developed. System consists of a database, database management system, model-base, model-base management system and a user interface [9]. In order to demonstrate the system's effectiveness, thereinafter, in shortly is addused the problem-solving example (see tab. 1). Three power-stations were analysed in this example i.e.: Ignalina nuclear power station, Kruonis pumped storage power plant, Kaunas hidroelectric power station according 3 groupes of the following criterion: macro (EU activity regulations, external political factors, internal political factors, changes in economic environment, support of the public, changes in industrial technologies, development of alternative energy sources); meso (state regulation of activities,. national legal framework, impact of state institutions and selfgovernment, possibility to get state guarantees, competitive environment, impact of environmental protection factors, safety of operations, dependence arising from supply of resources, integration of activity with international structures (interconnections), demand for innovations, cooperation with science and education institutions) and micro (state regulation of activities, national legal framework, impact of state institutions and self-government, possibility to get state guarantees, competitive environment, impact of environmental protection factors, safety of operations, dependence arising from supply of resources, integration of activity with international structures (interconnections), demand for innovations, cooperation with science and education institutions).

Table 1. Preliminary information for power-station sustainable development analysis

\begin{tabular}{|c|c|c|c|c|c|c|c|}
\hline No. & Criteria & $\begin{array}{l}\text { Measuring } \\
\text { units }\end{array}$ & $(+/-)$ & $\begin{array}{l}\text { Wights of } \\
\text { criteria }\end{array}$ & 1 & 2 & 3 \\
\hline 1 & EU activity regulations & points & + & 0.28 & 10 & 6 & 5 \\
\hline 2 & External political factors & points & - & 0.22 & 10 & 7 & 5 \\
\hline 3 & Internal political factors & points & - & 0.20 & 10 & 8 & 6 \\
\hline 4 & Changes in economic environment & points & + & 0.25 & 8 & 7 & 6 \\
\hline 5 & Support of the public & points & + & 0.35 & 10 & 7 & 5 \\
\hline 6 & Changes in industrial technologies & points & + & 0.11 & 8 & 8 & 6 \\
\hline 7 & Development of alternative energy sources & points & + & 0.05 & 5 & 6 & 6 \\
\hline
\end{tabular}




\begin{tabular}{|c|c|c|c|c|c|c|c|}
\hline 8 & State regulation of activities & points & - & 0.24 & 10 & 9 & 6 \\
\hline 9 & National legal framework & points & + & 0.18 & 8 & 6 & 6 \\
\hline 10 & Impact of state institutions and self-government & points & + & 0.12 & 9 & 7 & 8 \\
\hline 11 & Possibility to get state guarantees & points & + & 0.32 & 10 & 7 & 6 \\
\hline 12 & Competitive environment & points & + & 0.08 & 5 & 5 & 6 \\
\hline 13 & Impact of environmental protection factors & points & - & 0.15 & 6 & 5 & 5 \\
\hline 14 & Safety of operations & points & - & 0.25 & 6 & 5 & 6 \\
\hline 15 & Dependence arising from supply of resources & points & - & 0.08 & 7 & 5 & 5 \\
\hline 16 & $\begin{array}{l}\text { Integration of activity with international structures } \\
\text { (interconnections) }\end{array}$ & points & + & 0.22 & 8 & 7 & 6 \\
\hline 17 & $\begin{array}{l}\text { Demand for innovations, cooperation with science and } \\
\text { education institutions }\end{array}$ & points & + & 0.15 & 10 & 8 & 7 \\
\hline 18 & State regulation of activities & points & + & 0.18 & 8 & 8 & 8 \\
\hline 19 & National legal framework & points & + & 0.15 & 8 & 8 & 7 \\
\hline 20 & Impact of state institutions and self-government & points & + & 0.12 & 9 & 8 & 8 \\
\hline 21 & Possibility to get state guarantees & points & + & 0.18 & 9 & 8 & 7 \\
\hline 22 & Competitive environment & points & + & 0.20 & 10 & 8 & 8 \\
\hline 23 & Impact of environmental protection factors & points & + & 0.25 & 10 & 8 & 7 \\
\hline 24 & Safety of operations & points & + & 0.28 & 10 & 8 & 8 \\
\hline
\end{tabular}

As a result of the system's analysis we worked out that evaluating in completeness the priority macro,

meso, and micro criterias the most effective variation was 3 - Ignalina NPS (Table 2a; Table 2b).

Table 2a. Results of the system's analysis power-station sustainable development

\begin{tabular}{|c|c|c|c|c|c|c|c|}
\hline No. & Criteria under evaluation & $\begin{array}{l}\text { Mea-suring } \\
\text { units }\end{array}$ & $(+/-)$ & Weights & $\begin{array}{l}\text { Ignalina } \\
\text { NPS }\end{array}$ & $\begin{array}{l}\text { Kruonis } \\
\text { PSPP }\end{array}$ & $\begin{array}{l}\text { Kaunas } \\
\text { PSPP }\end{array}$ \\
\hline 1 & EU activity regulations & points & + & 0,2800 & 0,1333 & 0,0800 & 0,0667 \\
\hline 2 & External political factors & points & - & 0,2200 & 0,1000 & 0,0700 & 0,0500 \\
\hline 3 & Internal political factors & points & - & 0,2000 & 0,0833 & 0,0667 & 0,0500 \\
\hline 4 & Changes in economic environment & points & + & 0,2500 & 0,0952 & 0,0833 & 0,0714 \\
\hline 5 & Support of the public & points & + & 0,3500 & 0,1591 & 0,1114 & 0,0795 \\
\hline 6 & Changes in industrial technologies & points & + & 0,1100 & 0,0400 & 0,0400 & 0,0300 \\
\hline \multirow[t]{2}{*}{7} & $\begin{array}{l}\text { Development of alternative energy } \\
\text { sources }\end{array}$ & points & + & 0,0500 & 0,0147 & 0,0176 & 0,0176 \\
\hline & Meso level & & & & & & \\
\hline 8 & State regulation of activities & points & - & 0,2400 & 0,0960 & 0,0864 & 0,0576 \\
\hline 9 & National legal framework & points & + & 0,1800 & 0,0720 & 0,0540 & 0,0540 \\
\hline 10 & $\begin{array}{l}\text { Impact of state institutions and self- } \\
\text { government }\end{array}$ & points & + & 0,1200 & 0,0450 & 0,0350 & 0,0400 \\
\hline 11 & Possibility to get state guarantees & points & + & 0,3200 & 0,1391 & 0,0974 & 0,0835 \\
\hline 12 & Competitive environment & points & + & 0,0800 & 0,0250 & 0,0250 & 0,0300 \\
\hline 13 & $\begin{array}{l}\text { Impact of environmental protection } \\
\text { factors }\end{array}$ & points & - & 0,1500 & 0,0562 & 0,0469 & 0,0469 \\
\hline 14 & Safety of operations & points & - & 0,2500 & 0,0882 & 0,0735 & 0,0882 \\
\hline 15 & Dependence arising from supply of & points & - & 0,0800 & 0,0329 & 0,0235 & 0,0235 \\
\hline
\end{tabular}




\begin{tabular}{|l|l|c|r|r|r|r|r|}
\hline & resources & & & & & \\
\hline 16 & $\begin{array}{l}\text { Integration of activity with } \\
\text { international structures } \\
\text { (interconnections) }\end{array}$ & points & + & 0,2200 & 0,0838 & 0,0733 & 0,0629 \\
\hline 17 & $\begin{array}{l}\text { Demand for innovations, cooperation } \\
\text { with science and education institutions }\end{array}$ & points & + & 0,1500 & 0,0600 & 0,0480 & 0,0420 \\
\hline & Micro level & & & & & & \\
\hline 18 & $\begin{array}{l}\text { Exclusive (monopolistic) type of } \\
\text { activity }\end{array}$ & points & + & 0,1800 & 0,0600 & 0,0600 & 0,0600 \\
\hline 19 & Profitability indicators & points & + & 0,1500 & 0,0522 & 0,0522 & 0,0457 \\
\hline 20 & $\begin{array}{l}\text { Efficiency of implementation of } \\
\text { administrative management tools }\end{array}$ & points & + & 0,1200 & 0,0432 & 0,0384 & 0,0384 \\
\hline 21 & $\begin{array}{l}\text { Readiness to choose and implement } \\
\text { innovations }\end{array}$ & points & + & 0,1800 & 0,0675 & 0,0600 & 0,0525 \\
\hline 22 & $\begin{array}{l}\text { Experience of top managers of } \\
\text { companies }\end{array}$ & points & + & 0,2000 & 0,0769 & 0,0615 & 0,0615 \\
\hline 23 & Employment of qualifies specialists & points & + & 0,2500 & 0,1000 & 0,0800 & 0,0700 \\
\hline 24 & Application of IS & points & + & 0,2800 & 0,1077 & 0,0862 & 0,0862 \\
\hline
\end{tabular}

Table 2 b. Results of the system's analysis power-station sustainable development

\begin{tabular}{|l|r|r|r|}
\hline Total sum of maximizing normalized balanced rates $\mathrm{S}_{+\mathrm{j}}$ & 1.3747 & 1.1033 & 0.9919 \\
\hline Total sum of minimizing normalized balanced rates $\mathrm{S}_{-\mathrm{j}}$ & 0.4566 & 0.367 & 0.3162 \\
\hline Object's significance $\mathrm{Q}_{\mathrm{j}}$ & 1.6837 & 1.4878 & 1.4382 \\
\hline Object's utility degree $\mathrm{N}_{\mathrm{j}}$ & $100 \%$ & $88 \%$ & $85 \%$ \\
\hline Object's priority & 1 & 2 & 3 \\
\hline
\end{tabular}

\section{ENERGY INFRASTRUCTURE PROPERTY ASSESSMENT}

Companies' property assessment is performed for various purposes. It is regular that property assessment of companies and their infrastructure objects is performed while reorganising companies, striving that documents of companies' financial statements would reflect the market value of the company's property to the maximum, in order to attract investors and present activity and accounting documents to them that reflect the actual value of companies and property, when property is consolidated while performing large investment projects or when it is needed to establish property depreciation norms that would correspond to the market value of property replacement.

Assessment of companies as independent legal entities is often performed as the sum establishment of total value of business lines adding the market value of the "non-functioning" property objects which are not used in the assessed business lines. There are many cases in practice when property objects of companies have to be assessed separately without relating them with a complex of property or business line they belong to. This may be assessment in cases of sale, purchase, rent, writing-off, liquidation of separate objects. Property assessment is also important while writing off part of the property, when reconstruction is carried out or when equipment that is not worn out yet is replaced by more effective equipment. Moreover, property objects are assessed separately when their values are entered into accounting documents of companies. The value of companies' property is affected by the same consistent patterns as business.

Accordingly, various assessment methods and their combinations are applied for the assessment purpose. When assessing companies' business lines, value comparison, discounted cash flow and 
capitalization methods are used the most frequently; when assessing separate property objects, specifically engineering infrastructure objects, the cost of replacement method is applied (replacement cost minus depreciation). However, infrastructure companies are characterised by the specific activity and property used in operation. The activity of infrastructure companies is often in the sphere of state regulation, when the level of permissible costs is established, principles of pricing are set and economic decisions that are not based on market relations are accepted. Today, when establishing the value of infrastructure companies, it is necessary to find answers to questions how the exceptional (monopoly) type of the company activity and compliance with contemporary market requirements may be reflected in the property value, which methods are suitable when the price of the company's product or service is influenced by state regulation, how the negative impact on the environment should be integrated into the value of the company. Therefore, assessing the property and business of infrastructure companies, it is hard to apply regular assessment methods, and no clear methodologies, models or guidelines have been created how the property assessment of companies of infrastructure sector should be performed.

As an example, the property assessment results of one Lithuanian energy sector company, which encompasses high-tension power transmission grid and two power plants, are presented. After performing assessment by two methods, the cost of replacement method recommended for infrastructure and economic assessment - income capitalization method, two property values, which differ from each other almost twice, were received.

The received income capitalization value does not reflect the actual property creation costs, and due to this no depreciation sums necessary for such property renewal will be accumulated in the costs structure. The cost of replacement, showing the actual property value and its actual depreciation, would increase the company's expenses by property depreciation deduction groundlessly as regards the level of earned income. As depreciation costs are included while setting a service or product price, this would mean the increase of price for a user. Also, the conclusion may be made that the received level of income is too low to cover the expenses of present property renewal according to contemporary technologies and requirements of development principles [4].

Table 3. Comparison of results received by applying different assessment methods.

\begin{tabular}{|l|c|c|c|}
\hline $\begin{array}{c}\text { Name of the } \\
\text { company's } \\
\text { structural } \\
\text { unit }\end{array}$ & $\begin{array}{c}\text { Property } \\
\text { book } \\
\text { value, } \\
\text { thousand } \\
\text { EUR }\end{array}$ & $\begin{array}{c}\text { Actual } \\
\text { property } \\
\text { value } \\
\text { (established } \\
\text { by cost of } \\
\text { replacement } \\
\text { and value } \\
\text { comparison } \\
\text { methods) } \\
\text { thousand } \\
\text { EUR }\end{array}$ & $\begin{array}{c}\text { Property } \\
\text { value-in-use } \\
\text { (established } \\
\text { by income } \\
\text { capitalization } \\
\text { method), } \\
\text { thousand } \\
\text { EUR }\end{array}$ \\
\hline $\begin{array}{l}\text { Transmission } \\
\text { grid }\end{array}$ & 172728 & 598133 & 519304 \\
\hline $\begin{array}{l}\text { Kaunas } \\
\text { hydro power } \\
\text { plant }\end{array}$ & 10652 & 37020 & 21120 \\
\hline $\begin{array}{l}\text { Kruonis } \\
\text { pumped } \\
\text { storage } \\
\text { power plant }\end{array}$ & 100480 & 536812 & 133990 \\
\hline $\begin{array}{l}\text { Total } \\
\text { (established } \\
\text { property } \\
\text { value of the } \\
\text { company) }\end{array}$ & 283860 & 1171965 & 674414 \\
\hline
\end{tabular}

The exceptional feature of property of energy companies as well as of other infrastructure sector companies is its uniqueness. Infrastructure companies are specific, they have few analogues in the market and they are hardly comparable with each other. A big part of property of companies is created according to unique projects adapted to local requirements and possibilities, while the main installations of electricity producers (power plants) are designed and produced according to special projects. Thus, it is hard to apply the sales comparison method, which would reflect the market value the most objectively, while performing the assessment of the entire complex of property of an infrastructure company and while establishing the actual value of separate property groups (Table 3,). Furthermore, this method is used seldom due to very 
rare cases of sales of infrastructure companies in the open market.

As the energy price level is regulated, the level of costs is regulated accordingly as well. Therefore, property assessment by forecasting cash flows performed using discounted cash flow or capitalization methods will not always present an objective result of the value. Making an assessment by this method, investments into new, "clean" technologies, renewable energy resources are assessed as costs reducing income. When the value of an infrastructure company or its property objects is determined, in addition to criteria set by market conditions that influence the value of the company, it is necessary to define and assess criteria that enable to reflect the compliance of the company's technologies with the applied environmental protection requirements in the property value and to define criteria that correct the value of the company taking into regard investments into new technologies reducing pollution level; even though such investments are not always targeted at economic payback and they raise the level of property and operational costs.

It is usual that property of infrastructure companies is accounted by the cost of replacement. The cost of replacement method does not show the real market value, it is hard to apply this method while calculating the cost of replacement of specialpurpose constructions and installations that have been created long ago according to disused, outdated technologies and that are irrational by they physical volume. Still, this method in particular enables to determine the amortisation deductions of property necessary for the company's activity which have to be accumulated for the suitable and timely renewal of worn-out property. The main problem related with the application of cost of replacement method is that it may not be purposeful to replace certain property items under the changing economic activity conditions (for instance, when the demand, technologies change); as a result, the amortisation deductions for this property are not meaningful. When accounting is used for price regulation in companies of regulated activity, it is the regulating institution that accepts a decision on the permit to accumulate depreciation costs of a reappraised property item in activity costs, which would be reflected in the service or product price as well. Moreover, it is necessary to establish whether a specific property item is attributed to regulated activity or it serves for secondary activities of the company to which common market measures are applied. In companies providing public services and companies with pricing regulated by the state or municipalities, it is often attempted to set a too-long period of property depreciation, which enables the reduction of costs and price level respectively during a certain period; however, it limits the possibility to accumulate sufficient funds for the property modernisation and upgrading and to apply integrated ecological measures.

Still, companies have to perform periodic reappraisals of property due to market changes or other circumstances. This determines the increase of value of accounted property the most frequently. On the basis of accounting data of various energy companies of Central Europe, after the property assessment was performed, it was necessary to increase the book value by three and a half times. The growth of value registered in accounting is related with many factors; still, the most important is that, after starting to lean on market relations in their activity, infrastructure companies of Central and East European countries had to reorganise property accounting principles respectively and to start applying accounting methods recognised on the international level. After establishing the actual value of company and assessing its technological compliance, the pricing of services provided by the company should reflect actual property renewal costs, taking into account new ecology requirements for the activity of energy companies as well.

\section{ASSESSMENT OF ENERGY COMPANIES' ENVIRONMENTAL IMPACT - EXTERNAL COSTS}

The impact of various industrial activities on external environment is being analysed from the middle of the last century already after attention was paid to evidently negative after-effects of activity on the quality of human life and environment. External costs appear when certain social and economic activity affects the part of the society which is not 
related with this activity and when this impact and caused consequences are not compensated. Following the Fifth Environment Action Programme "Towards Sustainability", the European Union member states are searching for solutions and methods that would enable the integration of environmental parameters into economic activity indexes of companies assuring that the factor of environmental protection would be counted in while setting production costs and the correct price [1]. While the environmental impact made by a number of industrial sectors (especially chemistry, cellulose, etc.) has been studied more extensively, impact monitoring is performed, economic sanctions are applied, activity is regulated by the law and normative acts, few studies have been performed on the external impact of energy companies yet.

In the electric power field, external costs appear due to combustion products emitted by power plants to the environment - SO2, CO2, NOx as well as other hazardous particles, which harm human health, biological variety, quality of agricultural production, construction materials. Electromagnetic radiation caused by high-tension electricity installations affects the quality of life of people who live or work near such objects. Usually an electricity producer does not take into account the impact made on real estate, agriculture or health of people living around energy objects. In this case environmental protection costs are "external", even though society members incur actual costs due to decisions accepted by electricity producers. Electric power production, transmission and distribution costs are considered to be the most important criteria while accepting strategic and management decisions in the energy system. All direct activity costs are computed in them, including the property depreciation costs calculated from the actual property value. While companies are already making efforts that the cost of property replacement would reflect actual investments that comply with ecological requirements, the impact of atmosphere pollution and climate change on the environment and human health caused by the electric power production process should be assessed respectively too [1]. This impact has to cover the entire cycle from production to distribution rather than only the operation of power plants.
The power generation process covers separate cycles from production to supply to the user and systems that combine complicated technologies; therefore, in order to compare different kinds of damage caused by them, the transformation of a specific kind of damage into a monetary unit is made. ExternE methodology is considered the most suitable for damage calculated in the power sector - it is used to assess impacts by separate kinds of damage, the majority of which depend on the location of a power plant. After performing such assessment, damage costs are calculated, and external costs form the bigger part of them. After summing up internal and external costs, social costs are received [2]. For example, social costs incurred in companies that use renewable energy technologies for energy generation (wind, water, biomass) may be equal or even lower than the social costs of companies using regular organic fuel technologies despite the fact that advanced technologies are often expensive and predetermine high internal costs.

Seven kinds of damage were evaluated according to ExternE methodology, the main being impact on human health, crop, residential environment and buildings. It was taken into consideration that some kinds of pollutants affected not only the environment near energy objects but were carried away by rushes of wind and caused considerable damage many kilometres away from the source [6]. EcoSense software is used for making calculations. EcoSence encompasses combined models of air quality and impact assessment and a data base with entered initial data of all EU countries related thereto.

On the basis of results of the implemented CASES project, the means of external costs (due to classic air pollutants) have been calculated for 27 European Union member states in order to show typical and average conditions. While making the calculations, the emission results of the following pollutants have been received: NH3; NMVOC; NOX; PPMcoars; PPM25 and SO2. Assessing the impact on human health, fertility, damage to materials, "losses of biological variety", the territory of researched objects' location covered the entire Europe. The aim of the programme is the possibility to integrate external costs into power generation costs [6]. 
Table 4. External power generation costs in Lithuania in 2005, thousand EUR.

\begin{tabular}{|l|l|l|l|}
\hline & $\begin{array}{l}\text { PP (without } \\
\text { wind, } \\
\text { hydro, } \\
\text { biomass } \\
\text { fuel) }\end{array}$ & $\begin{array}{l}\text { Ignalina } \\
\text { NPP }\end{array}$ & $\begin{array}{c}\text { Total } \\
\text { external } \\
\text { costs in the } \\
\text { energy } \\
\text { system }\end{array}$ \\
\hline $\begin{array}{l}\text { External costs, } \\
\text { thousand EUR }\end{array}$ & 59697.2 & 59.3 & 59756.5 \\
\hline $\begin{array}{l}\text { Generation of } \\
\text { power } \\
\text { production, } \\
\text { MGWh }\end{array}$ & 3624 & 10338 & 14784 \\
\hline $\begin{array}{l}\text { External costs, } \\
\text { EUR/kWh }\end{array}$ & 0.02 & 0.00001 & 0.004 \\
\hline $\begin{array}{l}\text { External costs, } \\
\text { LTLcnt/kWh }\end{array}$ & 6.45 & 0.002 & 1.40 \\
\hline
\end{tabular}

According to reports of Lithuanian power plants on the emission amounts of classic pollutants from the main power generation sources furnished to the Ministry of Environment of Lithuania and according to assessments of damage costs performed using ExternE methodology, the calculation results of average external power generation costs in Lithuania are presented $[3,6]$ (Table 4).

The average power generation costs made 1.4 LTLent/kWh or 0.4 EURent/kWh per kilowatt-hour in Lithuania in 2005. The highest external costs were registered in thermal power stations burning fuel oil, and the lowest - in power plants burning natural gas. The lowest external power generation costs are incurred by Ignalina NPP as the nuclear power plant emits a very small amount of pollutants to the atmosphere. With Iganalia NPP operating, the external power generation costs were low in Lithuania in 2007 as well, despite the fact that Ignalina NPP generated slightly less electricity and the share of production of power plants using organic fuel increased. Nonetheless, the decommissioning of Ignalina NPP will make a big impact on the surge of average external power generation costs in Lithuania in 2009.

Lithuanian power plants are paying pollution taxes for emissions to the atmosphere. Still, these taxes are very small as compared with external costs. The increase of pollution taxes would influence the costs structure of energy sector companies. Specifically from 2009, when Lithuania will no longer have the cheap energy source - Ignalina Nuclear Power Plant.

Therefore, companies of electric power sector should prepare already now to take into account ecological requirements growing more stringent, pollution taxes, which will be increased in future, and integration of external costs into the company activity costs, while accepting decisions regarding the establishment of production prices, creation of new generation sources, investments and implementation of development programmes.

\section{CONCLUSION}

1. Strict environmental and technology renewal requirements related with environment protection are applied to infrastructure companies (electricity, gas, oil, heat and water supply, etc.). Making the assessment of special-purpose property of infrastructure companies, it is necessary to foresee additional factors that would reflect compliance with environmental requirements and norms, to determine the importance of these factors and to correct the assessed property values respectively. It is necessary to supplement the recommended economic infrastructure property assessment methods by more diverse methods enabling to determine the importance of various criteria and to specify the value result by these elements.

2. One of effective ways to encourage the use of renewable energy resources and to ground development, renovation and reconstruction projects is the replenishment of economic analysis of projects by the constituent of external energy generation costs.

3. The assessment of power generation costs in power plants using renewable energy resources (hydro and wind) in Lithuania applying ExternE values has shown that these technologies are exceptional by external energy generation costs that are from ten to several hundred times lower than those of power plants burning organic fuel; thus, assessing the value of energy sector companies by economic methods (discounted cash flow, income capitalization), it would be necessary to assess not only the direct incurred costs of companies but also all social costs. 


\section{REFERENCES}

[1] European Commission. (2004) Work Package 6: Revision of external cost estimates. In: New Elements for the Assessment of External Costs from Energy Technologies. Final Report. Contract No. ENGI-CT2000-00129.

[2] Hohmeyer, O. (1988) Social costs of energy consumption. Springer Verlag, Berlin.

[3] Norvaisa, E.; Galinis, A. (2004) Impact of external energy generation costs on functioning and sustainable development of the Lithuanian energy system. //Journal Energetika (Energy) 2004 No. 2. Publishing House of the Lithuanian Academy of Sciences (P).

[4] Sliogeriene J. (2007). The asset assessment in energy company to determine the asset of the actual value.

[5] Stasiskiene, Z.; Staniskis, J.K. (2005). "Environmental management accounting in Lithuania: exploratory study of current practices, opportunities and strategic intents" // Journal of Cleaner Production ISSN: 0959-6526. Elsevier Science.

[6] Streimikiene, D.; Pusinaite, R. External cost of electricity generation in Lithuania. // Journal Environment Research, Engineering and Management. Kaunas University of Technology.

[7] Schenler, W.W. (1999) Full value costs for sustainable electric utility options. International Journal of Global Energy Issues 1999 - Vol. 12, No.1/2/3/4/5/6 pp.208-217.

[8] WEC Statement (2001). Energy Markets: The Challenges of the New Millennium. Conclusions and Recommendations. 18th World Energy Congress. Buenos Aires - Argentina, 21-25 October, 2001

[9] Zavadskas E.K., L. Simanauskas, A. Kaklauskas (1998). Sprendimu paramos sistemos statyboje. Technika. Vilnius. 